\title{
Acoustic communication in the Red-vented Bulbul Pycnonotus cafer
}

\author{
ANIL KUMAR \\ Wildlife Institute of India, Post Box No. 18, Chandrabani, Dehradun-248001, Uttaranchal, India \\ Manuscript received on January 15, 2004; accepted for publication on February 5, 2004.
}

\begin{abstract}
This paper deals with acoustic communication in the Red-vented Bulbul Pycnonotus cafer. This species emits a high variety of vocal signals that can be classified on the basis of their acoustical features and context of production. Individuals sang throughout the year and most songs were discrete and stereotyped. The songs were composed of strophes (phrases) with minor structural variations of elements that were preceded and followed by a temporal gap ( 3 to 12s). Most strophes were composed of 2 to 6 elements that were often dissimilar in structure and ranging from 0.98 to $4.5 \mathrm{kHz}$. The biological function of the song appeared to be to maintain pair bonds and to synchronize breeding activities. Different types of context-specific calls were identified. Individuals produced Type-I alarm calls (fast and wide-band, 1.03 to $6.36 \mathrm{kHz}$ ) under low predation pressure and Type-II calls (narrow frequency range, 1.37 to $3.39 \mathrm{kHz}$ ) under high predation pressure. Roosting calls were fast and wide-band signals phonetically similar to Type-I alarm calls. Three types of begging/contact calls were recorded in nestlings/fledglings. Greeting calls and flight calls were composed of complex phrases, like song, but were short and used for proximate functions.
\end{abstract}

Key words: acoustic communication, Pycnonotus cafer, bird song, alarm calls, roosting calls, flight calls.

\section{INTRODUCTION}

Birds use a variety of acoustic signals in their communication. These signals may be long and complex or short and simple, and they may occur in particular contexts (Catchpole and Slater 1995). On the basis of physical characteristics and functional context, these signals can be classified into songs and calls. However, songs and calls are not always easily distinguished (Borowiec and Lontkowski 2000, Kumar 2003). Vocalizations uttered in a single articulation and generally made up of single elements (an element is a continuous sound, preceded and followed by a silent gap) are known as calls, while a typical song may include a continuous series of strophes/phrases (Catchpole and Slater 1995, Geoff 1996, Bhatt et al. 2000).

E-mail: anil_rathi@yahoo.com, anil@wii.gov.in
Generally, male birds use songs for territorial advertisement and mate attraction (Bhatt et al. 2000). In some cases, birds use songs for other purposes, such as to coordinate nest exchanges between mates (Smith 1988), inform females that there is no immediate threat of predation (Johnson and Kermott 1991), and distract potential predators (Ritchison 1991). In some bird species, females also sing (Ritchison 1983) such as in the Superb Fairy-Wren Malurus cyaneus (Cooney and Cockburn 1995) and Oriental Magpie-Robin Copsychus saularis (Kumar and Bhatt 2002). Bird song sometimes occurs outside the breeding season (Kelsey 1989). Calls are used in all seasons and play important roles in the sociobiology of birds, namely social contact, parentoffspring interactions, cohesiveness among flock/ family members, threat and danger (Geoff 1996). 
The Red-vented Bulbul Pycnonotus cafer is a tropical songbird, widely distributed throughout the Indian sub-continent, and common in gardens and light scrub jungle. It is a non-territorial species living in pairs to large flocks (Ali 1996, Grimmett et al. 1998). Although several aspects of its behavior and ecology have been well studied (Vijayan 1978), little is known about its vocalizations (Kumar and Bhatt 2000). In this paper, I describe vocalizations emitted by the Red-vented Bulbul and attempt to infer the behavioral significance of the signals.

\section{MATERIALS AND METHODS}

Recordings of 36 Red-vented Bulbuls were made in their natural habitats in Dehradun $\left(30^{\circ} 26^{\prime} \mathrm{N}\right.$; $78^{\circ} 06^{\prime}$ E) between May 2002 and June 2003. Some recordings were also made in Srinagar, Garhwal $\left(30^{\circ} 21^{\prime} \mathrm{N} ; 78^{\circ} 77^{\prime} \mathrm{E}\right)$, the lower hills of Mussoorie and Chilla range of Rajaji National Park, Haridwar $\left(29^{\circ} 55^{\prime} \mathrm{N} ; 78^{\circ} 08^{\prime} \mathrm{E}\right)$. The habitat of the main study area was sub-urban. All sites were within a $100 \mathrm{~km}$ radius. Sounds were recorded using Sony CFS 1030S or Sony PCM-M1 or Marantz PMD 222 sound recorders and JVC MZ-500 or Sennheiser ME-66 microphones. Behavioral correlates were used to infer the possible meanings of signals (Byers 1996).

These recordings were digitized using $\mathrm{M}$ Audiophile 2496 (sound card) at a sampling rate of 22.5 to $48 \mathrm{kHz}$ and 16-bit resolution. After editing, cuts of high quality recordings were analyzed with the help of Avisoft SAS Lab Pro (version 4.1) software. All spectrograms were produced with the following settings: 512 FFT-length, 75\% Frame, Hamming window and $87.5 \%$ time window overlap. In the present study, minimum frequency, maximum frequency, range of frequency, dominant frequency (frequency of maximal amplitude), duration and gap in signals were measured to define the acoustical features of the vocalizations. Number and types of elements, rate of production and complexity levels (types of elements per minute) were also measured. Results were expressed as mean \pm SE. Non- parametric statistics (Mann Whitney $U$-test) were used as most data were not normally distributed.

\section{RESULTS AND DISCUSSION}

\section{Physical Characteristics AND}

\section{Biological Significance of Songs}

Individuals sang throughout the year. 143 song samples (2-8 min. duration) were analyzed. Most songs were discrete type ( $88 \%$ of the total) composed of strophes (phrases) preceded and followed by temporal gaps. In a song bout, usually the same types of strophes were repeated several times in a stereotyped manner with minor structural variations of elements before switching to another type of strophe. For example, in figure 1A the element $a$ in phrase 1 is slightly different in structure to phrase 2 . Sometimes a single element type was found interjected between two distinct strophes $(n=16)$. Incomplete strophes were also identified $(n=23)$. Duration of strophes was 0.65 to $1.2 \mathrm{~s}(0.79 \pm 0.08, \mathrm{n}=124)$ and the gap between strophes was 3 to $12 \mathrm{~s}(4.64 \pm 0.06, \mathrm{n}=124)$. The frequency varied from 0.86 to $8.0 \mathrm{kHz}$, but in most phrases it varied from 1.5 to $4.5 \mathrm{kHz}$. Most strophes ( $n=93$ ) were composed of 2 to 6 elements that were often dissimilar in structure.

Behavioral observations revealed that the biological function of song in this species appeared to be to maintain pair-bonds and the synchronization of breeding activities. In some recordings (11.9\% of the total observations, $n=17$ ), singing rate (phrases per minute) and song complexity levels (types of elements per minute) were much higher (about four times) than in the other song recordings (Fig. 1B). It seems that the species used two categories of songs: Type-A songs (88.1\%) were commonly sung throughout the year to maintain pair-bonds, and Type-B songs (11.9\%) were more rare and most likely used for mating purposes.

In contrast with most temperate songbirds, male and female were observed singing throughout the year, but not dueting. In most cases $(n=78)$, only one bird (probably male) in a pair was observed singing at a time. Mate guarding was also observed. 

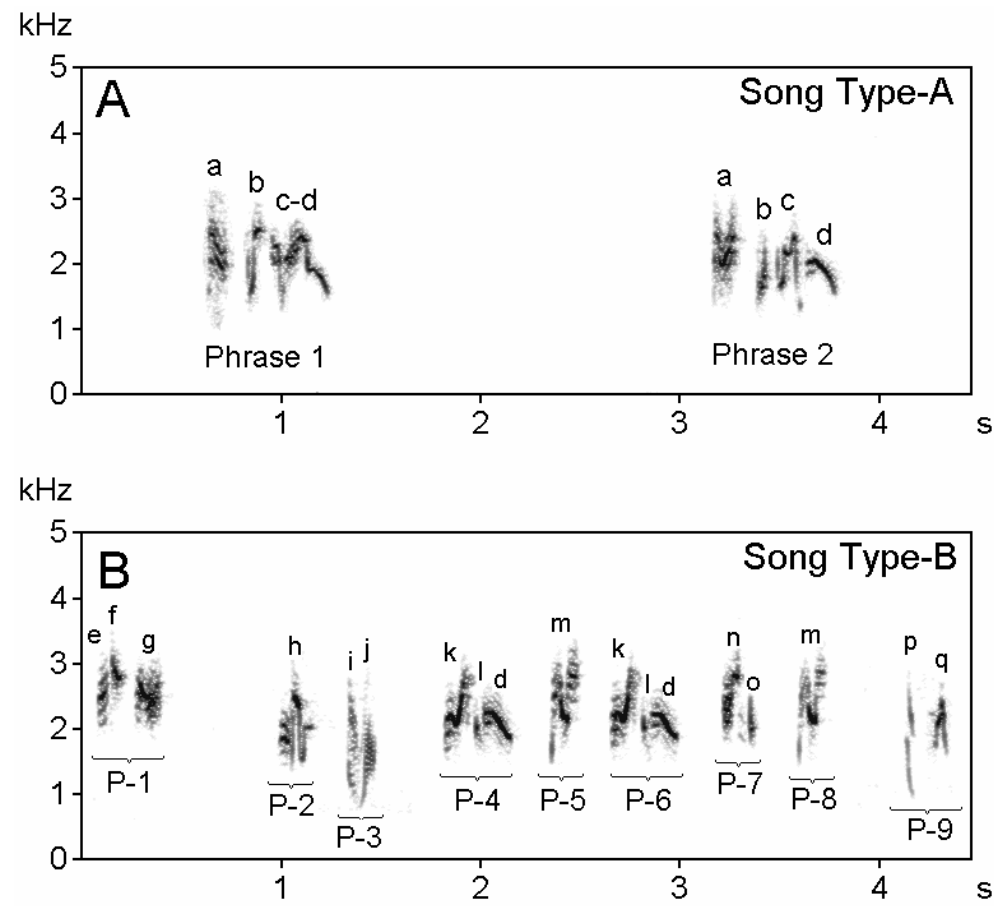

Fig. 1 - Sonograms of song in the Red-vented Bulbul. (A) Song Type-A composed of phrases with minor structural variations. (B) Song Type-B composed of short duration phrases (see $P-1$ to $P-9$ ) with irregular inter-phrase gaps and different types of elements. There is occasional sharing of elements between songs Type-A and Type-B. For example, element $d$ of phrase 2 in song Type-A is repeated in $P-4$ and $P-6$ in song Type-B.

In South Africa, some Pycnonotus species have been reported to use their vocalizations for territory advertisement (Lloyd et al. 1996), but in the current study no territorial conflict or advertisement was observed.

\section{Types of Calls and their Context of Production}

Different types of calls were identified. On the basis of their acoustic characteristics, these calls were classified into simple calls and complex calls.

(A) Simple calls: these calls were stereotyped, composed of elements with similar physical characteristics and structure, and made up of a series of monosyllabic notes.

1. Alarm calls. Two types of alarm calls were observed (Fig. 2).
Type I - When a predator such as sparrow hawk, eagle, tree-pie, owl, mongoose or cat appeared in the vicinity of the bird, the birds emitted Type I calls (phonetically rendered as twe...twe...twe...) and stood with erect crest (about 80 to 90 degree from horizontal plane) to alert the conspecifics. This was a fast, stereotyped sound composed of elements with wide frequency range ( 0.94 to $7.00 \mathrm{kHz}$ ). The average duration was $0.1 \pm 0.005 \mathrm{~s}$ with intervals of $0.12 \pm 0.01 \mathrm{~s}$. The rate of emission was $327 \pm 14$ notes per minute.

Two patterns of production were identified. Mostly, individuals produced elements with almost equal temporal gaps (Fig. 2A). In some cases, birds produce these elements in groups of 2 to 6 elements with larger inter-group gaps $(0.38 \pm 0.02, \mathrm{n}=18)$ (Fig. 2B). However, differences in the behavioral context were not seen. 

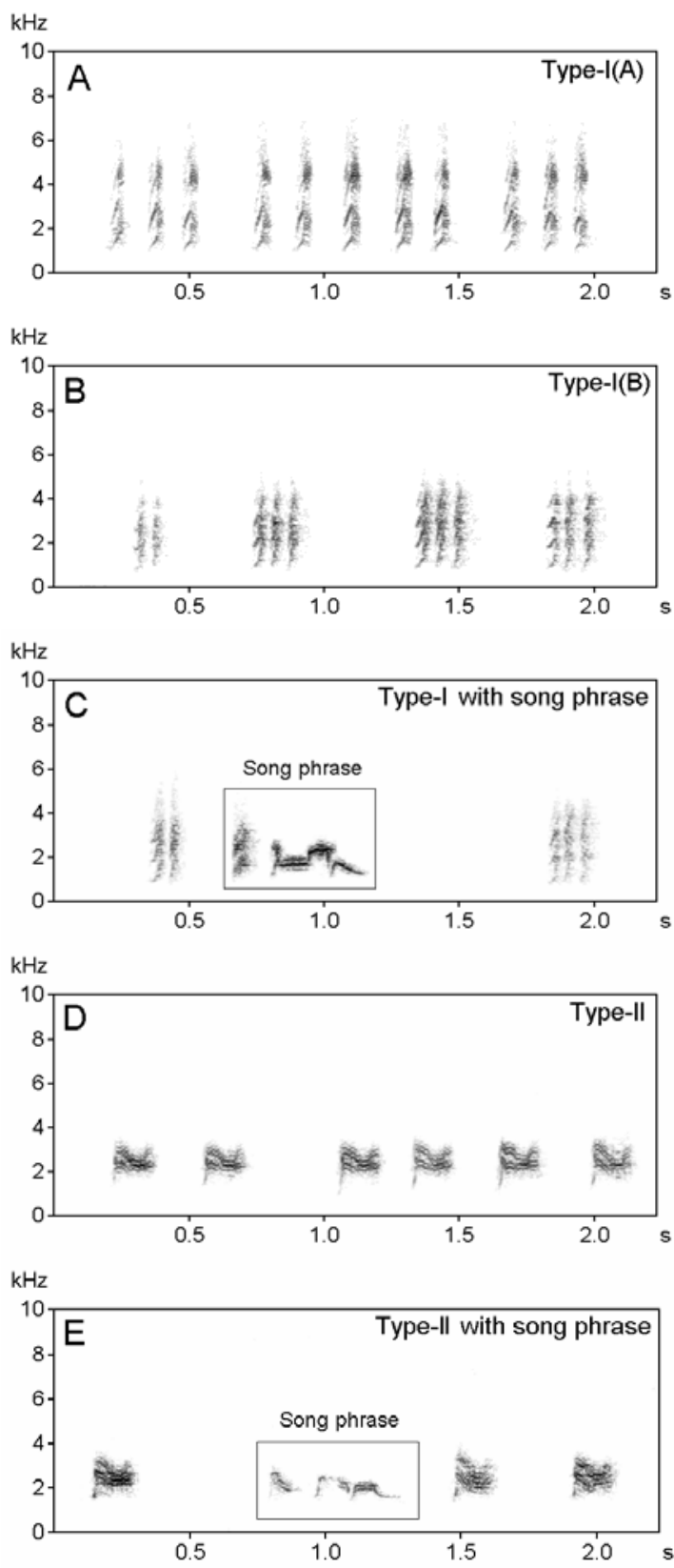

Fig. 2 - Sonograms of different types of alarm calls in the Red-vented Bulbul. A and B: alarm call Type-I with different temporal organizations, C: alarm calls (Type I) with song phrase, D: alarm call Type-II, and E: alarm call Type-II with song phrase.
Type II - Type II calls had a narrow frequency range (1.2 to $3.78 \mathrm{kHz}$ ) compared to Type-I calls (Mann Whitney $U$-test; $\mathrm{Z}=-5.99, \mathrm{P}<0.001)$. The duration of notes and interval was comparatively higher, while the rate of production was much lower than in Type-I calls $(\mathrm{Z}=-4.32, \mathrm{P}<0.001)$. The birds emitted Type-II calls when their nest or nestlings or fledglings were in high danger due to a closely located predator ( 20 to $30 \mathrm{~m}$ from the nest/ fledglings).

On occasion individuals used song phrases along with alarm calls. In both types of calls, phrases were identified (Fig. 2C and E). Acoustical features of these phrases were similar to the song. It seems that the birds used both signals alternatively, alarm calls to inform conspecifics and heterospecifics about danger and song phrases to contact their mates. Some bird species can recognize the vocalization of their mates (Lambrechts and Dhondt 1995), and each individual song repertoire may consist of a unique combination that may be individually distinctive (McGregor and Krebs 1982, Weary et al. 1990).

Like the Red-vented Bulbul, many avian species use more than one type of alarm call (Ficken and Popp 1996). Marler (1955) demonstrated the antithetical acoustic structure of two types of vocalizations elicited by predators. Calls given when a hawk is flying overhead are often high-pitched, cover a narrow frequency range, and lack abrupt onsets or terminations, while those given during mobbing cover a wide range of frequency and show abrupt onsets. Calls in the first category may have features making them difficult to localize, while mobbing calls have features enhancing localization (Marler and Hamilton 1966, Klump and Shalter 1984, Ficken et al. 1994, Ficken and Popp 1996). Red-vented Bulbul does participate in mobbing with other species uttering the same call.

2. Roosting calls. Most individuals roost in dense trees and bushes in flocks of 6 to 70 individuals. Bulbuls returned to the roost about 20 minutes (in the breeding season) to 1.5 hours (in winter) before sunset. The number of individuals in the roost- 
ing flock was minimum ( 2 to 8 individuals) in the breeding season, and highest (18 to 72) in the nonbreeding season. The roosting calls were very fast (206.9 \pm 8.1 elements per minute), broad band, frequency modulated signals produced by both sexes. Phonetically these signals may be rendered as twe...twe...twe..., very similar to alarm calls. Comparative analysis indicated that most physical characteristics of alarm calls were significantly different from the roosting calls $(\mathrm{P}<0.001)$. The minimum and maximum frequencies were $0.94 \pm 0.01$ and $5.54 \pm 0.07 \mathrm{kHz}$, respectively. The duration of elements was $0.09 \pm 0.03 \mathrm{~s}$ and intervals were $0.207 \pm 0.03 \mathrm{~s}$. At the roosting site, most birds used roosting calls with occasional song phrases. The song seemed to maintain social contact between pairs.

Roosting chorus has also been reported in a number of avian species (Wynne-Edwards 1962, Braestrup 1963, Siegfried 1971, Ward and Zahavi 1973, Khera and Kalsi 1986, Mahabal 1997, Wood 1999). Roosting behavior similar to that of the Redvented Bulbul has also been reported in the Redwhiskered Bulbul Pycnonotus jocosus at Wollongong in New South Wales, Australia, where it is an introduced species (Wood 1999). Like the Redvented Bulbul, the number of roosting birds was highest in winter and lowest in summer. In Florida, USA and Fiji, a similar seasonal abundance pattern was observed at communal roosts of the Redwhiskered Bulbul (Carleton and Owre 1975) and the Red-vented Bulbul (Watling 1983), respectively. It is believed that the individuals transfer information regarding food resources among flock members during communal roosting (Ward and Zahavi 1973). In addition, communal roosting may decrease the risk of predation (Lack 1968).

3. Begging calls. Two types of begging calls have been identified. Nestlings produced these vocalizations when the parents arrived at the nest. On the basis of physical characteristics, these calls can be classified as Type-I and Type-II (Fig. 3B and C). Type-I calls were simple, stereotyped, wide-band and composed of monosyllabic elements. The minimum and maximum frequencies were $0.69 \pm 0.06$ and $9.16 \pm 0.03 \mathrm{kHz}$, respectively. The average duration of elements was $0.17 \pm 0.006 \mathrm{~s}$ and the average interval between elements was $2.2 \pm 0.23 \mathrm{~s}$. The rate of these calls was $27.54 \pm 1.89$ elements per minute.

The nestlings were also observed using another type of call that was composed of simple, monosyllabic, stereotyped wide-band elements. The minimum and maximum frequencies were $1.27 \pm 0.05$ and $6.07 \pm 0.14 \mathrm{kHz}$, respectively. The average duration of elements was $0.11 \pm 0.04 \mathrm{~s}$ and the average duration of intervals was $0.56 \pm 0.04 \mathrm{~s}$. The average rate of emission was $98.91 \pm 3.99$ elements per minute. These calls were not observed in all individuals and the context of production was not clear. The parameters of these calls were significantly different from Type-I calls $(\mathrm{P}<0.001)$. It seems that these calls were either a developmental phase of another vocalization or were used for unknown specific purpose.

Like many other avian species, bulbuls use begging calls. Juveniles often direct vocal signals towards their parents, providing information on their condition (Weary et al. 1996). There is evidence from a number of studies that parental response varies in relation to calling by the nestlings. For example, young American White Pelicans Pelecanus erythrorhynchos produce a characteristic call when they are exposed to low ambient temperatures, and the likelihood of parents responding by brooding their chicks depends on the number of calls produced in a calling bout (Evans 1992, 1994). Similarly, when nestlings of the Magpie Pica pica were kept without food for a longer period, they increased the frequency of calls and their parents visited them more frequently (Redondo and Castro 1992). In the present study, we also observed that belated visits of parents to their nestlings provoked an increase in the delivery rate $(44.12 \pm 1.14$ elements per minute, $\mathrm{n}=8$ ) of begging calls.

The nestlings of most passerines beg for food by giving typical displays that consist of gaping, posturing, presenting their brightly colored gapes and 

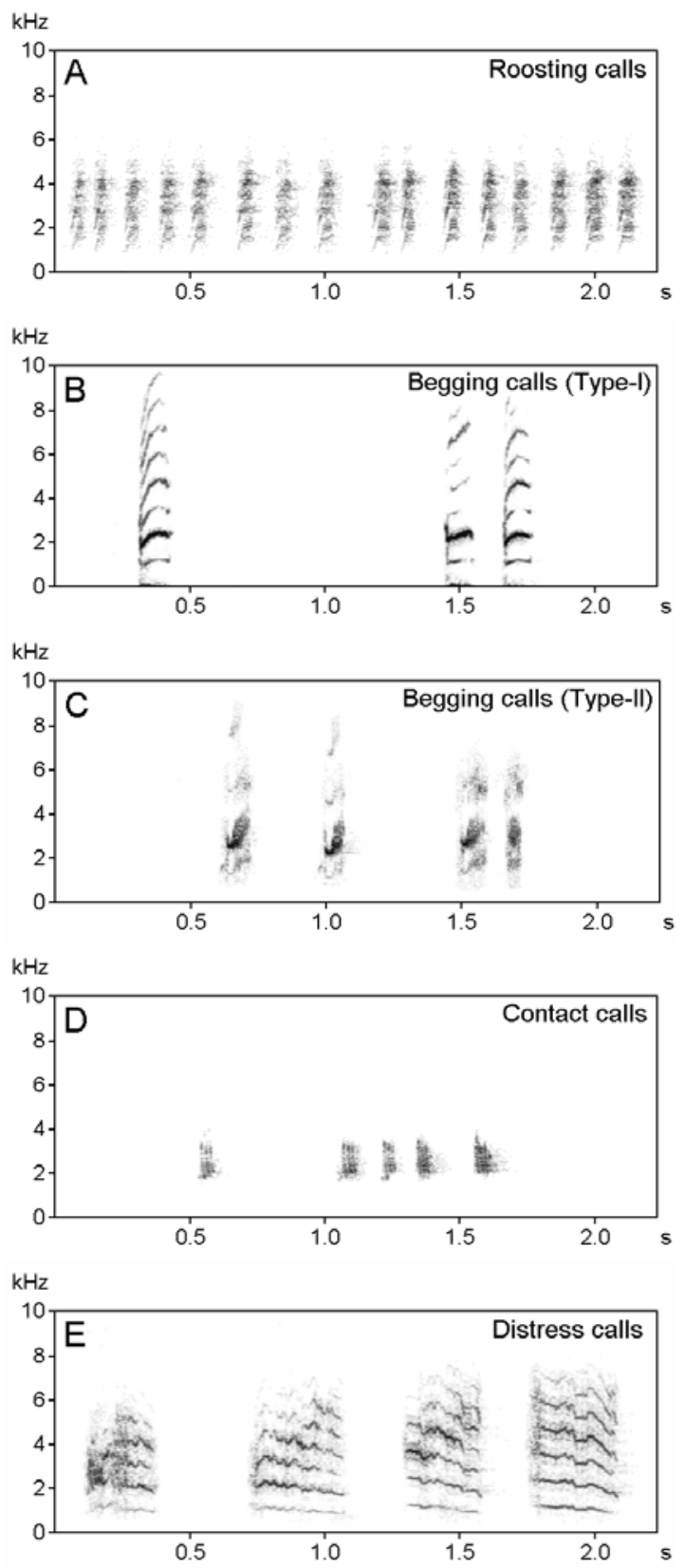

Fig. 3 - Sonograms of different types of calls emitted by the Red-vented Bulbul. A: roosting calls, B: Type-I begging calls, C: Type-II begging calls, D: contact calls, E: distress calls.

vocalizing loudly (Kilner and Johnstone 1997). The nestlings of Red-vented Bulbul have also been observed to use such bodily displays along with the begging calls.
4. Contact calls. Contact calls were recorded in late nestling phase and in fledgling phase. They consisted of a series of monosyllabic notes with a wide frequency range. The rate of delivery was 36$46(39.25 \pm 2.52)$ calls per minute in normal situations, but in belated visits the rate of delivery was higher (67 to 89 calls/ minute, $\mathrm{n}=11$ ). The minimum and maximum frequencies were $1.81 \pm 0.03$ and $3.74 \pm 0.06 \mathrm{kHz}$, respectively. The average duration of elements was $0.08 \pm 0.003 \mathrm{~s}$ and the average interval time between elements was $1.00 \pm 0.32 \mathrm{~s}$.

5. Distress calls. Distress calls were produced by nestlings and fledglings when they were captured by a predator, and when adults were handled for color banding. These signals were phonetically rendered like cheearr...chseerr..., and were composed of a wide range of frequencies $(0.7$ to $9.8 \mathrm{kHz})$ with overtones. The minimum and maximum frequencies were $0.75 \pm 0.06$ and $8.42 \pm 0.22 \mathrm{kHz}$, respectively. The average duration of elements was $0.29 \pm 0.008 \mathrm{~s}$ and the average interval between elements was $1.08 \pm 0.12 \mathrm{~s}$. The average rate of production was $39.8 \pm 6.2$ elements per minute (Fig. $3 \mathrm{E})$. These signals were used to get the help of conspecifics or heterospecifics.

(B) Complex calls: two types of complex calls were identified, greeting calls and flight calls (Fig. 4).

1. Greeting calls. When two individuals met, often one of them emitted a few low frequency, narrow band, low intensity vocalizations. Acoustical analysis revealed that these signals were composed of 1 to 3 song phrases in a bout. The structure was like the song, with different types of phrases composed of 2 to 10 elements. For example (Fig. 4A), a bird produced 10 elements of 6 types ( $a$ to $f$ and repetition of $c, d, e$ and $f$ ). The minimum and maximum frequencies were $1.93 \pm 0.04$ and $3.42 \pm 0.04 \mathrm{kHz}$, respectively. The average duration of elements was $0.39 \pm 0.02 \mathrm{~s}$ and the call interval was $0.068 \pm 0.007 \mathrm{~s}$. It seems that the biological function of these calls was to maintain social contact between individuals. In South Africa, three other species of Pycnonotus have been reported to use greeting calls in a similar 

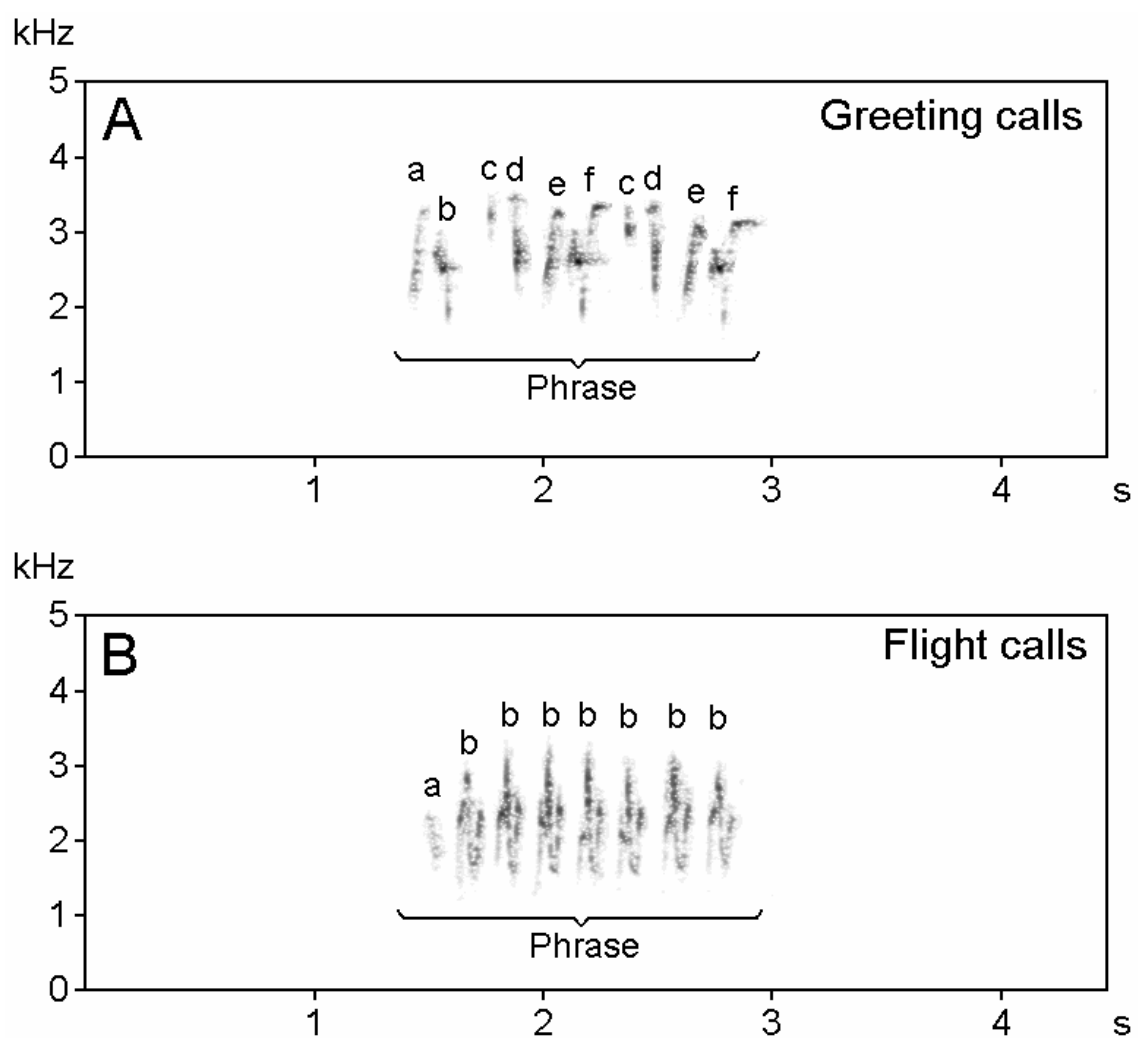

Fig. 4 - Sonograms of complex calls in the Red-vented Bulbul. A: Greeting calls: one phrase composed of different types of elements. B: Flight calls: one phrase composed of 2 types of elements.

fashion (Lloyd et al. 1996).

2. Flight calls. Flight calls were song-like vocalizations produced by the bird just before flight and in flight. It was a narrow-band signal composed of one or two phrases. The phrases were different in different bouts. The average minimum and maximum frequencies were $1.34 \pm 0.03$ and $3.36 \pm 0.06 \mathrm{kHz}$, respectively. The average duration of elements was $0.19 \pm 0.03 \mathrm{~s}$ and the average call interval $1.057 \pm 0.005 \mathrm{~s}$. This vocalization was low intensity, slow and produced by both male and female individuals.

\section{CONCLUSION}

The Red-vented Bulbul is a suitable model to study communication systems of birds in India because it is a commonly available species and easily main- tained in cage for experiments. The birds are often familiar with humans and allow close recordings. In the wild, they nest in bushes near human settlements and, with their nests at only 1-5 meter height, studying parents-offspring signaling behavior is not difficult.

Twenty-one species of bulbuls (Pycnonotidae) exist in the Indian subcontinent (Grimmett et al. 1998), with some being endemic and/or rare. It appears that closely related species exhibit quite similar social organization, but little information is available on this aspect. The Red-vented Bulbul can also be used as a model to study a wide array of questions related to evolution, behavioral ecology and sociobiology such as individual and mate vocal recognition, modes of information transfer through simple or complex vocal signals, and adaptation of singing behavior to diverse habitats. 


\section{ACKNOWLEDGMENTS}

I am grateful to Director, WII for encouraging and extending me institutional facilities and Dr. Dinesh Bhatt, Gurukul Kangri University, Haridwar for the suggestions during the study. I am thankful to Ajeet Singh, Romesh Kumar Sharma, Ashish Kumar and Rajah Jayapal for their cooperation at various levels during the study. Financial support from DST under SERC Fast Track scheme (Project no. SR/FTP/LS$166 / 2000)$ is also gratefully acknowledged.

\section{RESUMO}

Este artigo trata da comunicação acústica do bubulco Pycnonotus cafer. Esta espécie emite uma grande variedade de sinais vocais que podem ser classificados com base nas suas características acústicas e no contexto de emissão. Os indivíduos vocalizaram ao longo do ano e muitos dos cantos foram distintos e estereotipados. Os cantos foram compostos de estrofes (frases) com mínimas variações estruturais de elementos, sons precedidos e seguidos por um espaço temporal ( 3 a 12s). Muitas estrofes foram compostas de 2 a 6 elementos que foram freqüentemente diferentes na estrutura e variaram de 0,98 a 4,5 kHz. A função biológica do canto parece ser para manutenção dos casais e sincronia das atividades reprodutivas. Diferentes tipos de gritos relacionados a contextos específicos foram identificados. Os indivíduos produziram gritos de alarme do Tipo-I (rápidos e de larga faixa de freqüência; 1,03 a $6,36 \mathrm{kHz}$ ) sob baixa pressão de predação e os gritos de alarme do Tipo-II (estreita faixa de freqüência; 1,37 a 3,39 kHz) sob alta pressão de predação. Gritos de congregação noturna foram rápidos e de larga faixa de frequiência, foneticamente similares aos gritos de alarme do Tipo-I. Três tipos de gritos de pedido de alimento/contato foram gravados em ninhegos/filhotes saídos do ninho. Gritos de cumprimento e gritos de vôo foram compostos por frases complexas, como o canto, mas foram curtos e usados para funções de proximidade.

Palavras-chave: comunicação acústica, Pycnonotus cafer, canto de ave, gritos de alarme, gritos de congregação noturna, gritos de vôo.

\section{REFERENCES}

ALI S. 1996. The book of Indian birds. Mumbai: Oxford University Press.
Bhatt D, Kumar A, Singh Y and Payne RB. 2000. Territorial songs and calls in Oriental Magpie-Robin Copsychus saularis. Curr Sci 78: 722-728.

Borowiec M AND LontKowsKi J. 2000. Sexual selection and the evolution of song in birds of the genus Acrocephalus. Biol Bull Ponzan 37: 69-77.

BraEstrup FW. 1963. The functions of communal displays. Dansk Ornithol Foren Tiddskr 57: 133-142.

Byers BE. 1996. Messages encoded in the songs of Chestnut-sided Warblers. Anim Behav 52: 691-705.

Carleton AR and Owre OT. 1975. The Red-whiskered Bulbul in Florida: 1960-71. Auk 92: 40-57.

Catchpole CK and Slater PJB. 1995. Bird song: Biological themes and variations. Cambridge: Cambridge University Press.

Cooney R And Cockburn A. 1995. Territorial defense is the major function of female song in the Superb Fairy-Wren (Malurus cyaneus). Anim Behav 49: 1635-1647.

Evans RM. 1992. Embryonic and neonatal vocal elicitation of parental brooding and feeding responses in American White Pelicans. Anim Behav 44: 667-675.

Evans RM. 1994. Cold-induced calling and shivering in young American White Pelicans: Honest signaling of offspring need for warmth in a functionally integrated thermoregulatory system. Behaviour 129: 13-34.

Ficken MS AND PopP J. 1996. A comparative analysis of passerine mobbing calls. Auk 113: 370-380.

Ficken MS, Hailman ED and Hailman JP. 1994. The Chick-a-dee call system of the Mexican Chickadee. Condor 96: 70-82.

GeofF S. 1996. Bird songs and calls of Britain and northern Europe. London: Harper Collians Publ.

Grimmett R, InsKipP C AND INSKIPP T. 1998. Birds of the Indian subcontinent. London: Oxford University Press.

Johnson LS AND Kermott LH. 1991. The functions of song in male House Wrens (Troglodytes aedon). Behaviour 116: 190-206.

Kelsey MG. 1989. A comparison of the song and territorial behaviour of a long-distance migrant, the Marsh Warbler Acrocephalus palustris in summer and winter. Ibis 131: 403-414.

Khera S AND Kalsi RS. 1986. Waking and roosting behaviour of the Bank Myna, Acridotheres gingini- 
anus, in Chandigarh and surrounding areas. Pavo 24: 55-68.

KILNER R AND Johnstone RA. 1997. Breeding the question: are offspring solicitation behaviours signals of need? Trends Ecol Evol 12: 11-15.

Klump GM and Shalter MD. 1984. Acoustic behaviour of birds and mammals in the predator context. Z Tierpsychol 66: 189-226.

Kumar A. 2003. Acoustic communication in birds: Differences in songs and calls, their production and biological significance. Resonance 8: 44-55.

Kumar A And Bhatt D. 2000. Vocal signals in a tropical avian species the Red-vented Bulbul Pycnonotus cafer: Their characteristics and importance. J Biosci 25: 387-396.

Kumar A and Bhatt D. 2002. Characteristics and significance of song in female Oriental Magpie Robin Copsychus saularis. J Bombay Nat Hist Soc 99: 54-58.

LACK D. 1968. Ecological adaptations for breeding in birds. London: Methuen.

LAMBrechts MM AND Dhondt AA. 1995. Individual voice discrimination in birds. Curr Ornith 12: 115-139.

Lloyd P, Hulley PE and Craig AJPK. 1996. Comparisons of the vocalizations and social behaviour of southern African Pycnonotus bulbuls. Ostrich 67: 118-125.

Mahabal A. 1997. Communal roosting in Common Mynas Acridotheres tristis and its functional significance. J Bombay Nat Hist Soc 94: 342-349.

MARLER P. 1955. Characteristics of some animal calls. Nature 176: 6-8.

Marler P ANd Hamilton J. 1966. Mechanisms of animal behaviour. New York: John Wiley and Sons.

McGregor PK ANd Krebs JR. 1982. Song types in a population of Great Tits (Parus major): their distribution, abundance, and acquisition by individuals. Behaviour 79: 126-152.
RedOndo T And Castro F. 1992. Signaling of nutritional need by Magpie nestlings. Ethology 92: 193-204.

Ritchison G. 1983. The function of singing in female Black-headed Grosbeaks (Pheucticus melanocephalus): family-group maintenance. Auk 100: 105-116.

Ritchison G. 1991. The flight songs of Common Yellowthroats: Description and causation. Condor 93: 12 18.

SiEgFrIED WR. 1971. Communal roosting of the Cattle Egret. Trans Roy Soc S Afr 39: 419-443.

Sмiтн WJ. 1988. Patterned daytime singing of the Eastern Wood-Pewee Contopus virens. Anim Behav 36: 1111-1123.

ViJAYAn VS. 1978. Breeding biology of bulbuls Pycnonotus cafer and Pycnonotus luteolus (Class: Aves, Family: Pycnonotidae) with special reference to their ecological isolation. J Bombay Nat Hist Soc 75: 1090-1117.

WARD P AND ZAhavi A. 1973. The importance of certain assemblages of birds as 'information centers' for food finding. Ibis 115: 517-534.

WatLING D. 1983. The breeding biology of the Redvented Bulbul Pycnonotus cafer in Fiji. Emu 83: 173-180.

Weary DM, Norris KJ and Falls JB. 1990. Song features birds use to identify individuals. Auk 107: 623-625.

Weary DM, Lawson GL and Thompson BK. 1996. Sows show stronger responses to isolation calls of piglets associated with greater levels of piglet need. Anim Behav 52: 1247-1253.

WooD KA. 1999. Roosting habits of the Red-whiskered Bulbul at Wollongong, New South Wales. Australian Bird Watcher 18: 75-80.

Wynne-EdWARds VC. 1962. Animal dispersion in relation to social behaviour. Edinburgh: Oliver and Boyd. 